\title{
Karbon Nanopartiküllerin Epoksi Yapıştırıcılarda Etkilerinin İncelenmesi
}

\author{
Sinan AYDIN*1 \\ ${ }^{1}$ Sivas Cumhuriyet Üniversitesi, Teknoloji Fakültesi, Mekatronik Mühendisliği Bölümü, Sivas
}

Geliş tarihi: 10.07.2019 Kabul tarihi: 30.09 .2019

$\ddot{\mathbf{O z}}$

Günümüzde aynı veya farklı türlerdeki malzemelerin birleştirilmesi için kolay uygulanabilme ve ekonomik olmaları nedeniyle yapıştırıcılar oldukça fazla kullanılmaktadır. Gelişen teknoloji ve üretim yöntemleriyle beraber hemen hemen her alan için ihtiyaç duyulan yapıștırıcılar üretilmektedir. Yapıştırıcıların özelliklerinin iyileştirilmesi için çalışmalar yapılmaktadır. Çalışmada, epoksi yapıştırıcıların içerisine karbon nanopartikül eklenerek oluşturulan yapıştırma bağlantılarında nanopartikül oranının pürüzlü yüzeylerdeki yapışma dayanımına etkileri araştırılmıştır. Yapıştıııcılara, yapıştırıcı ağırlığının \%0,5 ile \%5'i aralığındaki oranlarda nanopartiküller eklenerek deneyler yapılmıştır. Nanopartiküllerin belirli bir orana kadar yapışma dayanımına olumlu etki gösterdiği sonrasında ise bu etkilerinin azaldığı görülmüştür.

Anahtar Kelimeler: Nanopartikül, Epoksi yapıştırıcı, Yüzey pürüzlülük

\section{Investigation of Effects of Carbon Nanoparticles on Epoxy Adhesives}

\begin{abstract}
Nowadays, adhesives are widely used because they are easy to apply and economical for joining the same or different types of materials. With the developing technology and production methods, adhesives needed for almost every field are produced. Efforts are being made to improve the properties of adhesives. In this study, effects of nanoparticle ratio on adhesion strength on rough surfaces were investigated in bonding joints formed by adding carbon nanoparticle into epoxy adhesives. Experiments were carried out by adding nanoparticles in the range of $0.5 \%$ to $5 \%$ of the adhesive weight. Nanoparticles showed a positive effect on adhesion strength up to a certain rate, and after that, these effects decreased.
\end{abstract}

Keywords: Nanoparticle, Epoxy adhesive, Surface roughness

*Sorumlu yazar (Corresponding author): Sinan AYDIN, sinancan@cumhuriyet.edu.tr 


\section{GíRiș}

Yapıştırıcılar, aynı veya farklı malzemeden yapılmış yüzeyler arasında bir çeşit köprü görevi yapmaktadır. Yapışma mekanizması, adhezyon ve kohezyon kuvveti olmak üzere iki kuvvete bağlıdır. Adhezyon kuvveti, iki maddenin temas yüzeylerindeki yapışma kuvveti yani yapıştırıcının yüzeye yapışma kuvvetidir. Kohezyon kuvveti ise yapıştırıcı molekülleri arasında bulunan ve yapıştırıcıyı bir arada tutan yapıştırıcının iç kuvvetidir [1].

Yapıştırıcılar, birleştirme işlemi sonucunda beklenilen mekanik özelliklerin yanı sıra termal ve 1sıl özelliklerinde sağlayabilmeleri için tek veya çok bileşenli olarak üretilmektedir. Son zamanlarda nanopartiküllerin belirli oranlarda yapıştırıcılara eklenmesi durumunda bu özelliklerdeki değişimler araştırılmaya başlanmıştır.

Kuang-Ting ve arkadaşları [2], Grafit fiber/epoksi kompozit malzemeleri yapıştırmak için çok duvarlı karbon nanotüplerin farklı ağırlıktaki miktarlarını kullanarak ve kompozit plakalara kayma dayanımı testi uygulamışlardır. Elde ettikleri sonuçlara göre kullanılan nanotüp miktarının artırılmasıyla birlikte ortalama kayma dayanımında da artış olduğunu belirtmişlerdir. En yüksek kayma dayanımının ağırlıkça $\% 5$ oranında karbon nanotüp kullanılmasıyla elde edildiğini ifade ederek bunun karbon nanotüp ilaveli yapıştırıcı bağlantılarında kompozit fiber grafit yüzeylerinde oluşan hasarlardan kaynaklandığını tespit etmişlerdir.

Panta ve arkadaşları [3], Farklı türlerde nanopartikül katılmış epoksi yapıştırıcılarıyla oluşturulan tekli bindirme bağlantılarında kayma dayanımını ve reolojik özelliklerini incelemişlerdir. Nanopartikül ilavesi sayesinde epoksinin termal stabilitesinin arttığını ve kayma dayanımının nanopartikül türüne göre $\% 53, \% 49$ ve $\% 46$ oranlarında arttığını belirlemişlerdir.

Florian ve arkadaşları [4], tek duvarlı karbon nanotüp (SWCNT), çift duvarlı karbon nanotüp (DWCNT) ve çok duvarlı karbon nanotüp
(MWCNT) kullanılarak oluşturulan epoksi bazlı nano kompozitlerin mekanik özelliklerinin ve yüzey fonksiyonlarının değerlendirilmesini yapmışlardır. Elde ettikleri sonuçlara göre ağırlıkça \%0,5 oranında çift duvarlı karbon nanotüp (DWCNT) kullanılması ile sertlik artmış ve kırılma tokluğu \%43 oranında artış göstermiştir.

Saeed ve Zhan [5], çok duvarlı karbon nanotüp ilaveli (MWCNT) kompozit poliimid filmlerdeki yapıştırıcı dayanımı üzerine yaptıkları çalışmalarında kopma mukavemeti ve elastiklik modülü artışının ağırlıkça yüzde oranı ile arttığını ancak belirli bir kritik değerden sonra azaldı $\breve{g}_{1}$ belirlemişlerdir. Kritik değeri poliimid türüne bağlı olarak $\% 1$ ve $\% 0,5$ olarak tespit etmişlerdir.

Lanlan ve arkadaşları [6] farklı nanoparçacıkların epoksi yapıştırıcı içerisine farklı oranlarda karıştırılması ile çelik plaka üzerinde oluşturulan bağlantının farklı yüzey pürüzlülük değerlerindeki mukavemetini incelemişlerdir. Çalışmalarında \%2 $\mathrm{Al}_{2} \mathrm{O}_{3}$ nanoparçacık içeren karışımın 150 kumluk zımpara ile parlatılan yüzeylerde elde edilen mukavemet değerinin nanoparçacık kullanılmadığ 1 durumlardakine oranla 5 kat daha fazla çıktığını tespit etmişlerdir.

Gültekin ve arkadaşları [7] Grafen takviyeli epoksi yapıştırıcıda nanoparçacık oranının bağlantıdaki hasar yüküne etkilerini araştırmak için çalışma yapmışlardır. Çalışmalarında ağırlıkça $\% 0,5-1$ ve 2 olmak üzere 3 farklı partikül oranı ve farklı karışım yöntemleri uygulayarak oluşturdukları tek bindirmeli bağlantılarda (single lap joint) deneyler yapmışlardır. En yüksek hasar yükü dayanımını $\% 1$ partikül oranında tespit etmişler ve partikül oranının artmasıyla hasar yükünün azaldığını belirtmişlerdir.

Akpinar ve arkadaşları [8], nanoparçacık eklenmiş yapıştırıcı ile birleştirilmiş tek bindirmeli bağlantılarda çekme ve eğilme momenti hasar yükünü deneysel olarak incelemişlerdir. Çalışmalarında yapıştırılan malzeme olarak kullandıkları karbon fiber kumaş takviyeli kompozit ve AA2024-T3 alüminyum alaşımı sert, esnek yapıştırıcı kullanarak ve içerisine ağırlıkça $\% 1$ oranında grafen, karbon nanotüp ve fullerene 
C60 ekleyerek birleştirmişlerdir. Sonuç olarak yapıştırıcı türü ve nanoparçacık türüne göre hasar yükünün arttığını belirtmişlerdir.

May ve arkadaşları [9] modifiye epoksi/hibrid çözelti yapışkan içerisindeki nano dolgu maddelerinin yapıştırma bağlantısı üzerindeki etkilerini incelemek için çok duvarlı karbon nanotüp (MWCNT) ve $\mathrm{Al}_{2} \mathrm{O}_{3}$ kullanarak çekme ve kayma testleri yapmışlardır. Çalışmalarında nanoparçacık kullanıldığında bağlantı dayanımının saf epoksiye göre önemli derecede arttığını ifade etmişlerdir.

Wernik ve Meguid [10], karbon nanotüp ile güçlendirilmiş epoksi yapıştırıcının mekanik özelliklerini deneysel olarak incelemişlerdir. Çalışmalarında farklı test yöntemlerini kullanarak farklı oranlarda nanotüp oranlarında oluşturulan bağlantıların özelliklerini analiz etmişlerdir. Elde ettikleri sonuçlara göre yapıştrıma bağlantılarında kritik nanotüp oranının \%1.5 olduğunu belirlemişler ve bu değerin aşılması ile özelliklerin azaldığını tespit etmişlerdir

Razavi ve arkadaşları [11], silika nanoparçacıklar ve çok duvarlı karbon nanotüplerin karıştırılması ile güçlendirilmiş epoksi yapıştırıcının mekanik özelliklerini incelemişlerdir. Çalışmalarında ağırlıç̧a \%0,2 \%0,5 ve \%0,8 olmak üzere 3 farklı partikül oranı kullanmışlardır. Mekanik özelliklerin nanoparçacık eklenmesiyle iyileştiğini ve özellikle $\% 0,8$ oranında en yüksek değerleri elde etmişlerdir.

Douba ve arkadaşları [12] Nanopartiküllerin polimer betonun çeliğe bağlanma dayanımı üzerindeki etkilerini incelemişlerdir. Çok Duvarlı Karbon Nanotüpler, Alüminyum Nanopartiküller $\left(\mathrm{Al}_{2} \mathrm{O}_{3}\right)$ ve Silica Nanopartikülleri (SNP) etkilerini incelemek için epoksi tabanlı bir Polymer concrete (PC)ye eklemişlerdir. Bağ dayanımını belirlemek için eğimli kayma testleri kullanmışlardır. Çalışmalarında nanopartikül oranını ağırlıkça $\% 0,5, \quad \% 1$ ve $\% 2$ olarak kullanmışlardır. Nanopartiküllerin bağ gücünü artırdığını özellikle ANP'lerin bağ gücünü $\% 51$ oranında artırdığını tespit etmişlerdir.
Andrew ve arkadaşları [13], Yüksek içsel eksenel 1sıl iletkenliklerinden dolayı yeni nesil termal ara yüz malzemesi olarak çok ilgi çeken karbon nanotüp (CNT) dizilerinde oluşan termal sınır direncini incelemişlerdir. Oluşturdukları yeni bir ara yüz sayesinde düşük 1sıl direnç ve yüksek mekanik uyumluluğu göstermişlerdir.

Yu ve arkadaşları [14]. Alüminyum plakaları yapıştırmak için karbon nanotüp (CNT) takviyeli epoksi yapıştırıcı geliştirmişler ve bağlantının termal, elektriksel ve mekanik özelliklerini incelemişlerdir. Artırılan nanotüp miktarı ile elektrik iletkenliği ve termal kararlılığın arttığını belirlemişlerdir. Mekanik testlerde ise eğilme dayanımının ve tokluğun arttığını ancak ağırlıkça \%1 karbon nanotüp oranından sonra tokluğun azaldığını belirtmişlerdir.

Chena ve arkadaşları [15] karbon nanotüp ile güçlendirilmiş epoksi reçine kompozitlerin tribolojik özelliklerine dispersiyon yönteminin etkilerini araştırmışlardır. Çalışmalarında çift asimetrik santrifüj, sonikasyon ve elle karıştırma yöntemlerini kullanarak karşılaştırma yapmışlardır. Ön işlem görmüş parçacıkların sonikatör kullanıldığında aşınarak hasar gördüklerini bu yüzden bu tipteki parçacıklarda sonikatör kullanılmamasını belirtmişlerdir. Çift asimetrik santrifüjün verimli bir şekilde epoksi reçinesi içindeki CNT'leri dağıttığını ürettiği yüksek kesme gerilmesi sayesinde aglomeraları parçalara ayırmak için etkili bir yol olduğunu ifade etmişlerdir.

$\mathrm{Bu}$ çalışmada, epoksi yapıştırıcıların içerisine nanopartikül eklenerek oluşturulan yapıştırma bağlantılarında nanopartikül oranının pürüzlü yüzeylerdeki yapışma dayanımına etkileri araştırılmıştır.

\section{MATERYAL VE METOT}

Çalışmada, öncelikle saf halde iki farklı epoksi yapıştırıcı (Pattex-Selsil) ile ince (\#180) ve kalın zımparalanmış (\#60) alüminyum levhalar ve dolly yapıştırılmıştır. Daha sonra bu yapıştırıcılara ağırlıkça $\% 0,5-\% 5$ aralığındaki oranlarda $7 \mathrm{~nm}$ ve 
20 nm çapındaki çok duvarlı karbon Deneylerde kullanılan malzemeler Şekil 1'de nanopartiküller katılarak oluşturulan bağlantıların yapışma dayanımları adhezyon testleri yapılarak incelenmiştir.

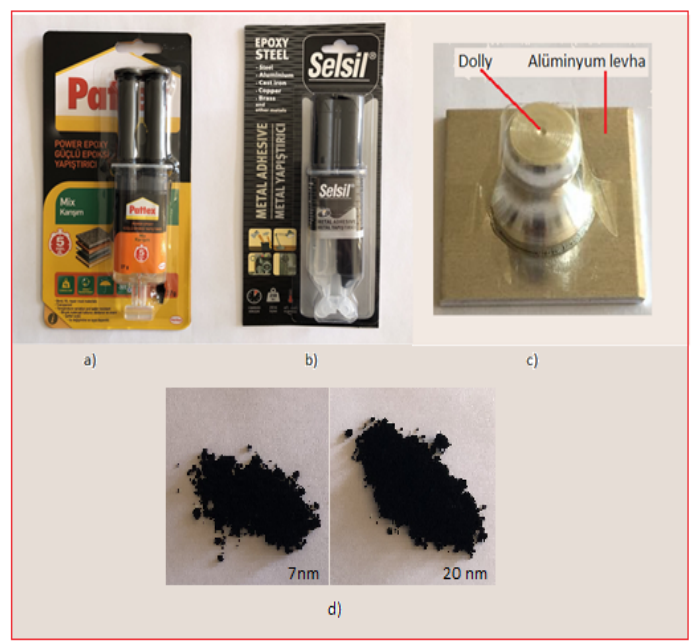

Şekil 1. Deney malzemeleri a) Pattex b) Selsil c) Alüminyum levha ve dolly d) Karbon nanopartiküller

Yapıştırıcı olarak; epoksi reçine ve bu epoksi reçinelere ait özel sertleştirici aktivatör içeren, çift bileşenli piyasada yaygın olarak kullanılan Pattex ve Selsil adlı iki farklı metal yapıştırıcı kullanılmıştır. Yapıştırıcıların teknik özellikleri Çizelge 1'de verilmiştir

Çizelge 1. Yapıştırıcıların teknik özellikleri

\begin{tabular}{|l|c|c|}
\hline Yapıştırıcı & Pattex & Selsil \\
\hline Yük taşıma & $130 \mathrm{~kg} / \mathrm{cm}^{2}$ & $250 \mathrm{~kg} / \mathrm{cm}^{2}$ \\
\hline Isı dayanımı $\left({ }^{\circ} \mathbf{C}\right)$ & $(-20)-(+120)$ & $(-40)-(+120)$ \\
\hline Kürleşme süresi & 5 dakika & 5 dakika \\
\hline
\end{tabular}

Yapıştırılan malzemeler olarak alüminyum plaka (5005 alaşımında, H14/H24 sertliğinde, çekme dayanımı: $145-185 \mathrm{~N} / \mathrm{mm}^{2}$, akma dayanımı: $110 \mathrm{~N} / \mathrm{mm}$ ve boyutları: $40 \mathrm{~mm}$ x $40 \mathrm{~mm}$ x $3 \mathrm{~mm}$ ) ve alüminyum dolly (test cihazı çekme parçası) (çap: $20 \mathrm{~mm}$ ) kullanılmıştır. Nanopartikül olarak iki adet çok duvarlı karbon nanopartikül (renk: siyah, çap: 7 ve $20 \mathrm{~nm}$, saflık: ağırlıkça >\%95) kullanılmıştır. Alüminyum levha ve dolly için yapıştırma işleminden önce yüzey hazırlık ve temizleme işlemleri uygulanmıştır. $\mathrm{Bu}$ işlemlerde ilk olarak alüminyum levha C-60 kumlu silikon karpit kalın zımpara (\#60) ve C-180 kumlu silikon karpit ince zımpara (\#180) ile pürüzlendirilmiştir. $\mathrm{Bu}$ işlemin ardından deney numuneleri, üzerinde bulunan kir, yağ ve toz vs. gibi yabancı maddelerin temizlenmesi için aseton ile yıkama ve durulama yapılmıştır. En son işlem olarak etüv içerisinde $50{ }^{\circ} \mathrm{C}$ 'de 30 dakika kurutma işlemi yapılarak levhalar ve dolly yapıştırma işlemine hazır hale gelmiştir. (Şekil 2.a)

Nanopartikül katkılı yapıştırıcıların hazırlanması için temiz beher içerisine; yapıştırıcıların birinci bileşeni olan epoksi reçine, reçine ağırlığının $\% 0,5-\% 5$ 'i oranında nanopartikül ve epoksi reçine ağırlığının iki katı kadar aseton eklenerek ultrasonik karıştırıcıda $30 \mathrm{KHz}$ frekansta 10 dakika karıştırma yapılmıştır. Karışım içindeki asetonun buharlaşması için $30{ }^{\circ} \mathrm{C}$ etüv içerisinde bekletilmiştir. Son işlem olarak epoksi reçine ve nanopartikül karışımı üzerine her yapıştırıcının ikinci bileşeni olan sertleştirici eklenerek mekanik karıştırıcıda 5 dakika düşük devirde karıştırma işlemi yapılmıştır. Karıştırma işlemi bittikten sonra her nanopartikül oranı için bu işlemler tekrar tekrar yapılarak deney numuneleri hızlı ve dikkatli bir şekilde yapıştırılmıştır (Şekil 2.b). Yapıştırma direnci, ASTM D 4541 ve ISO 4624 standartlarına 
göre Positest Pull-off adhezyon test cihazı ile ölçülmüştür. Ortalama bir değer elde edebilmek için her koşul için 5 numune test edilmiştir [16].
Çalışmada kullanılan cihazlar Şekil 3'de verilmiştir.

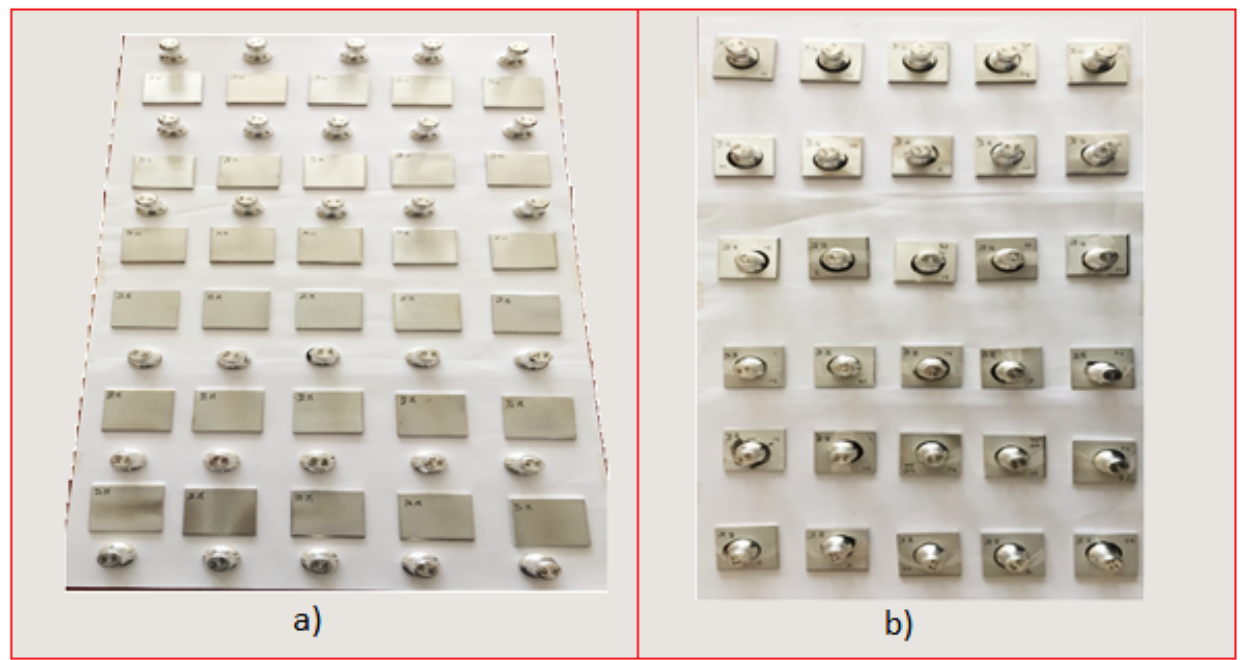

Şekil 2. Deney numuneleri a) yapıştırma öncesi b) yapıştırma sonrası

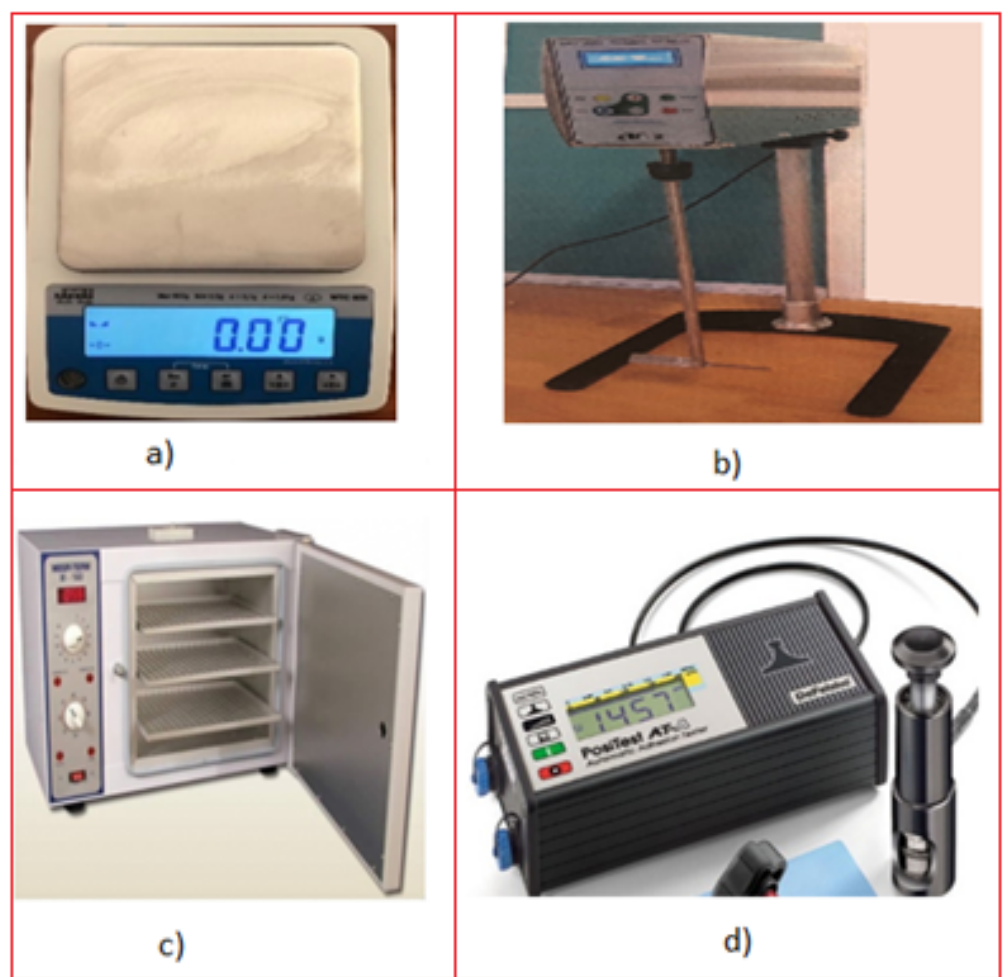

Şekil 3. Deney cihazları a) Hassas terazi b) Mekanik karıştırıcı c) Etüv d) Pull-off test cihazı 


\section{BULGULAR VE TARTIŞMA}

Şekil 4'de Pattex yapıştırıcısına ait $7 \mathrm{~nm}$ ve $20 \mathrm{~nm}$ çapında, ağırlıkça \%1 oranında nanopartiküllerin katılmasıyla oluşturulan yapıştırma bağlantısının kalın zımpara (\#60) ve ince zımpara (\#180) ile pürüzlendirilmiş yüzeylerdeki pull-off testi SEM görüntüleri verilmiştir. Şekilde dolly üzerindeki koyu olarak görülen bölgelerde yapıştırma bağlantısı ara yüzeylerinde yapıştırıcı tabakanın kırılması ile yapıştırıcıda meydana gelen kohezyon hasarı görülmektedir. Kullanılan yapıştırıcının alüminyum levha ve dolly gibi metal yüzeylerden malzeme koparacak kadar güçlü olmaması sebebiyle bu yüzeylerde malzeme kopması sonucu oluşan adhezyon hasarı meydana gelmemiştir. Şekildeki kopma bölgesi detay görüntülerinde ise nanopartiküllerin yapıştırıcı içerisinde homojen bir şekilde dağıldığı görülmektedir.

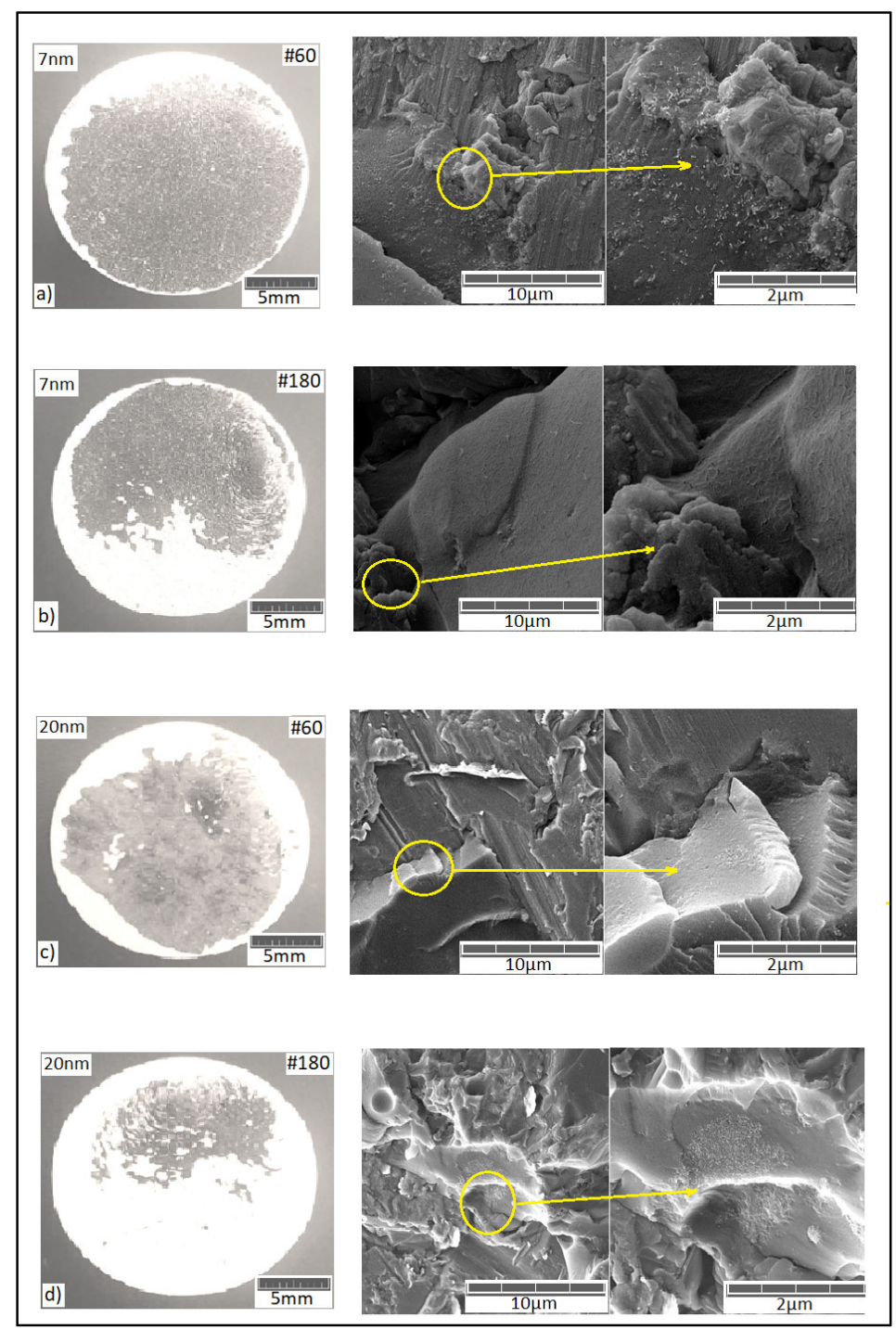

Şekil 4. Pattex \%1 nanopartikül katkılı SEM görüntüleri, a) 7nm - \#60 b) $7 \mathrm{~nm}-\# 180$ c) $20 \mathrm{~nm}$ - \#60 d) $20 \mathrm{~nm}-\# 180$ 
Şekil 5'de Selsil yapıştırıcısına ait $7 \mathrm{~nm}$ ve $20 \mathrm{~nm}$ çapında, ağırlıkça \%1 oranında nanopartiküllerin katılmasıyla oluşturulan yapıştırma bağlantısının kalın zımpara (\#60) ve ince zımpara (\#180) ile pürüzlendirilmiş yüzeylerdeki pull-off testi SEM görüntüleri verilmiştir. $\mathrm{Bu}$ yapıştırıcı kullanıldığındada dolly ve alüminyum levha üzerindeki yapışma yüzeyinde yapıştırıcı tabakanın kırılması ile yapıştırıcıda kohezyon hasarı meydana gelmiştir. Dolly ve levha üzerinden malzeme kopmaması sebebiyle bu yüzeylerde de adhezyon hasarı meydana gelmemiştir. Kopma bölgesi detay görüntülerinde nanopartiküllerin aglomere olmadan yapıştırıcı içerisinde homojen bir şekilde dağıldığı görülmektedir.

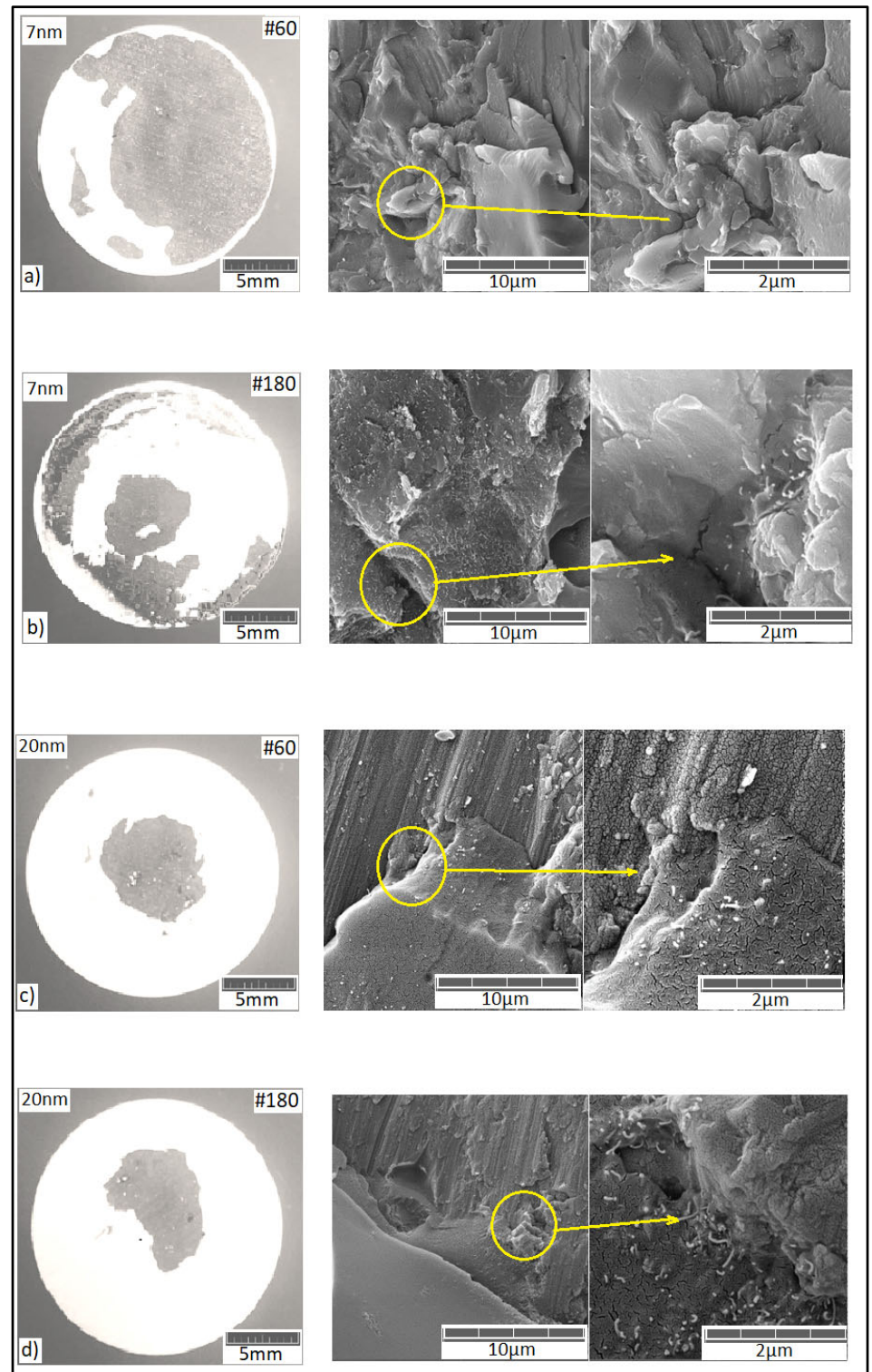

Şekil 5. Selsil \%1 nanopartikül katkılı SEM görüntüleri, a) $7 \mathrm{~nm}$ - \#60 b) $7 \mathrm{~nm} \mathrm{-} \mathrm{\# 180} \mathrm{c)} 20 \mathrm{~nm}$ - \#60 d) $20 \mathrm{~nm}$ - \#180 
Yapıştırıcıların nano partikül eklenmeden (katkısız) ve nanopartikül katılmış durumda oluşturulmuş bağlantılarının adhezyon testleri sonucunda elde edilen yapışma dayanımı değişimleri Şekil 6 ve Şekil 7'de gösterilmiştir.

Pattex yapıştırıcı kullanılması durumunda, (Şekil 6a ve Şekil 6b) katkısız haldeki yapışma mukavemeti; ince zımparalı (\#180) yüzeyde 1,62 $\mathrm{MPa}$ iken, kalın zımparalı (\#60) yüzeyde 2,34 MPa olarak elde edilmiştir. Kalın zımparalı yüzeyde yapıştırıcı iyi bir tutunma sağladığı için yapışma dayanımı ince zımparalı yüzeye göre yüksek çıkmıştır.

İnce zımparalı (\#180) yüzeyde $7 \mathrm{~nm}$ çaplı partikül için yapışma dayanımı \%2 partikül oranına kadar artış göstererek maksimum değer \%2 karışım oranında 2,20 MPa olarak elde edilmiştir. Yapışma dayanımı, nanopartikül eklenmesi ile \%36 artmıştır. \%2 partikül oranından sonra yapışma dayanımı azalarak \%5 nanopartikül oranında katkısız hale göre \%39 azalma göstermiştir.

İnce zımparalı (\#180) yüzeyde $20 \mathrm{~nm}$ çaplı partikül için yapışma dayanımı maksimum değer
\%2 karışım oranında 2,61 MPa olarak elde edilmiştir. Yapışma dayanımı, nanopartikül eklenmesi ile \%61 artmıştır. \%2 oranından sonra yapışma dayanımı azalarak \%5 nanopartikül oranında katkısız hale göre \%36 azalma göstermiştir.

Kalın zımparalı (\#60) yüzeyde $7 \mathrm{~nm}$ çaplı partikül için yapışma dayanımı \%2,5 partikül oranına kadar artış göstererek maksimum değer \%2,5 karışım oranında 3,49 MPa olarak elde edilmiştir. Yapışma dayanımı, nanopartikül eklenmesi ile \%49 artmıştır. \%2,5 partikül oranından sonra yapışma dayanımı azalarak \%5 nanopartikül oranında katkısız hale göre \%24 azalma göstermiştir.

Kalın zımparalı (\#60) yüzeyde $20 \mathrm{~nm}$ çaplı partikül için yapışma dayanımı maksimum değer \%2,5 karıșım oranında 3,96 $\mathrm{MPa}$ olarak elde edilmiştir. Yapışma dayanımı, nanopartikül eklenmesi ile \%69 artmıştır. \%2,5 oranından sonra yapışma dayanımı azalarak \%5 nanopartikül oranında katkısız hale göre $\% 10$ azalma göstermiştir.

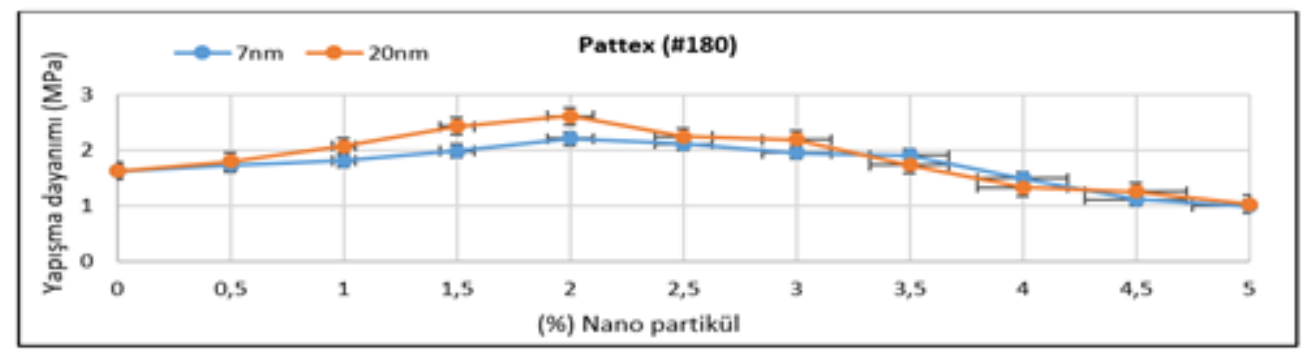

a)

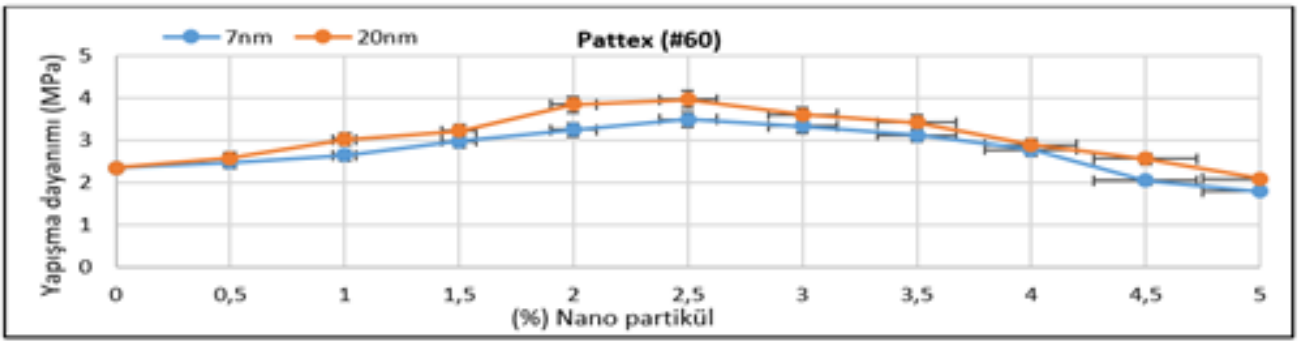

b)

Şekil 6. Farklı yüzey pürüzlülükleri için nanopartikül oranına bağlı olarak yapışma dayanımının değişimi a) Pattex \#180 b) Pattex \#60 
Selsil yapıştırıcı kullanılması durumunda, (Şekil 7a ve Şekil 7b) katkısız haldeki yapışma mukavemeti; ince zımparalı (\#180) yüzeyde 2,79 $\mathrm{MPa}$ iken, kalın zımparalı (\#60) yüzeyde 3,07 MPa olarak elde edilmiştir. Bu yapıştırıcıda kalın zımparalı yüzeyde yapıştırıcı iyi bir tutunma sağladığı için yapışma dayanımı ince zımparalı yüzeye göre yüksek çıkmıştır.

İnce zımparalı (\#180) yüzeyde $7 \mathrm{~nm}$ çaplı partikül için yapışma dayanımı \%2 partikül oranına kadar artış göstererek maksimum değer \%2 karışım oranında 3,31 MPa olarak elde edilmiştir. Yapışma dayanımı, nanopartikül eklenmesi ile \%18 artmıştır. \%2 partikül oranından sonra yapışma dayanımı azalarak \%5 nanopartikül oranında katkısız hale göre $\% 52$ azalma göstermiştir.

İnce zımparalı (\#180) yüzeyde $20 \mathrm{~nm}$ çaplı partikül için yapışma dayanımı maksimum değer \%2 karışım oranında 3,72 MPa olarak elde edilmiştir. Yapışma dayanımı, nanopartikül eklenmesi ile \%33 artmıștır. \%2 oranından sonra yapışma dayanımı azalarak \%5 nanopartikül oranında katkısız hale göre $\% 45$ azalma göstermiştir.

Kalın zımparalı (\#60) yüzeyde $7 \mathrm{~nm}$ çaplı partikül için yapışma dayanımı \%2,5 partikül oranına kadar artış göstererek maksimum değer \%2,5 karışım oranında 5,45 MPa olarak elde edilmiştir. Yapışma dayanımı, nanopartikül eklenmesi ile \%77 artmıştır. \%2,5 partikül oranından sonra yapışma dayanımı azalarak \%5 nanopartikül oranında katkısız hale göre $\% 17$ artış göstermiştir.

Kalın zımparalı (\#60) yüzeyde $20 \mathrm{~nm}$ çaplı partikül için yapışma dayanımı maksimum değer \%2,5 karışım oranında 6,61 $\mathrm{MPa}$ olarak elde edilmiştir. Yapışma dayanımı, nanopartikül eklenmesi ile \%115 artmıştır. \%2,5 oranından sonra yapışma dayanımı azalarak $\% 5$ nanopartikül oranında katkısız hale göre $\% 1$ artış göstermiştir.

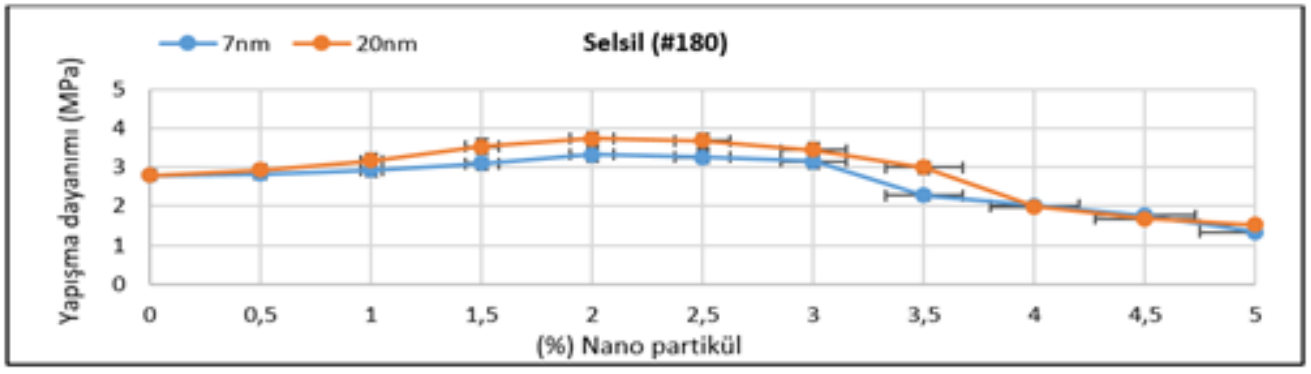

a)

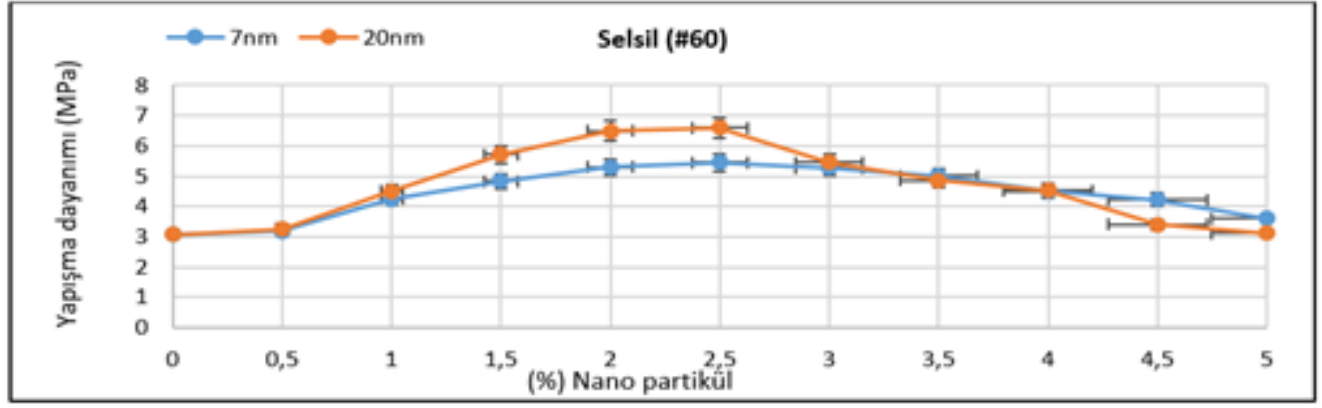

b)

Şekil 7. Farklı yüzey pürüzlülükleri için nanopartikül oranına bağlı olarak yapışma dayanımının değişimi a) Selsil \#180 b) Selsil \#60 
Katkısız ve nanopartikül katkılı yapıştıııılarla oluşturulan bağlantıların yapışma dayanımları ve katkısız hale göre yapıştırma dayanımındaki \% değişim miktarları Çizelge 2'de verilmiştir.

Çizelge 2. Yapıştırıcıların nanopartikül oranlarına göre yapışma dayanımları ve \%değişim miktarları

\begin{tabular}{|c|c|c|c|c|c|c|c|c|c|c|c|c|c|c|c|c|c|c|c|c|c|c|}
\hline \multicolumn{23}{|c|}{ Pattex (\#180) } \\
\hline & \multicolumn{11}{|c|}{ Partikül boyutu: 7 nm } & \multicolumn{11}{|c|}{ Partikül boyutu: $20 \mathrm{~nm}$} \\
\hline \begin{tabular}{|l|}
$\begin{array}{l}\text { Partikül } \\
\text { oranı } \\
(\%)\end{array}$ \\
\end{tabular} & 0 & 0,5 & 1 & 1,5 & 2 & 2,5 & 3 & 3,5 & 4 & 4,5 & 5 & 0 & 0,5 & 1 & 1,5 & 2 & 2,5 & 3 & 3,5 & 4 & 4,5 & 5 \\
\hline \begin{tabular}{|l} 
Yapıșma \\
dayanımı \\
(Mpa)
\end{tabular} & 1,62 & 1,73 & 1,81 & 1,98 & 2,21 & 2,11 & 1,95 & 1,9 & 1,49 & 1,11 & 0,99 & 1,62 & 1,79 & 2,06 & 2,42 & 2,61 & 2,24 & 2,18 & 1,73 & 1,33 & 1,25 & 1,03 \\
\hline \multicolumn{12}{|c|}{ Yapıșma dayanımı standart sapma: 0,38} & \multicolumn{11}{|c|}{ Yapışma dayanımı standart sapma: 0,5} \\
\hline \begin{tabular}{|l|} 
Yapışma \\
dayanımı \\
değişim \\
$(\%)$
\end{tabular} & 0 & 6 & 11 & 22 & 36 & 30 & 20 & 17 & -8 & -31 & -39 & 0 & 10 & 27 & 49 & 61 & 38 & 34 & 6 & -17 & -22 & -36 \\
\hline \multicolumn{23}{|c|}{ Pattex (\#60) } \\
\hline & \multicolumn{11}{|c|}{ Partikül boyutu: $7 \mathrm{~nm}$} & \multicolumn{11}{|c|}{ Partikül boyutu: $20 \mathrm{~nm}$} \\
\hline \begin{tabular}{|l|}
$\begin{array}{l}\text { Partikül } \\
\text { oranı } \\
(\%)\end{array}$ \\
\end{tabular} & 0 & 0,5 & 1 & 1,5 & 2 & 2.5 & 3 & 3,5 & 4 & 4,5 & 5 & 0 & 0,5 & 1 & 1,5 & 2 & 2,5 & 3 & 3,5 & 4 & 4,5 & 5 \\
\hline \begin{tabular}{|l|} 
Yapışma \\
dayanımı \\
(Mpa)
\end{tabular} & 2,34 & 2,47 & 2,64 & 2,97 & 3,25 & 3,49 & 3,33 & 3,11 & 2,77 & 2,04 & 1,79 & 2,34 & 2,57 & 3,02 & 3,21 & 3,84 & 3,96 & 3,6 & 3,42 & 2,89 & 2,56 & 2,09 \\
\hline \multicolumn{12}{|c|}{ Yapışma dayanımı standart sapma: 0,54} & \multicolumn{11}{|c|}{ Yapıșma dayanımı standart sapma: 0,61} \\
\hline \begin{tabular}{|l|} 
Yapışma \\
dayanımı \\
değişim \\
$(\%)$
\end{tabular} & 0 & 5 & 12 & 27 & 38 & 49 & 42 & 32 & 18 & -13 & -24 & 0 & 9 & 29 & 37 & 64 & 69 & 53 & 46 & 23 & 9 & -10 \\
\hline \multicolumn{23}{|c|}{ Selsil (\#180) } \\
\hline & \multicolumn{11}{|c|}{ Partikül boyutu: $7 \mathrm{~nm}$} & \multicolumn{11}{|c|}{ Partikül boyutu: $20 \mathrm{~nm}$} \\
\hline \begin{tabular}{|l|}
$\begin{array}{l}\text { Partikül } \\
\text { oranı } \\
(\%)\end{array}$ \\
$\%$
\end{tabular} & 0 & 0,5 & 1 & 1,5 & 2 & 2.5 & 3 & 3,5 & 4 & 4,5 & 5 & 0 & 0,5 & 1 & 1,5 & 2 & 2,5 & 3 & 3,5 & 4 & 4,5 & 5 \\
\hline \begin{tabular}{|l|} 
Yapışma \\
dayanımı \\
(Mpa)
\end{tabular} & 2,79 & 2,82 & 2,92 & 3,09 & 3,31 & 3,25 & 3,14 & 2,27 & 2,01 & 1,77 & 1,33 & 2,79 & 2,93 & 3,17 & 3,53 & 3,72 & 3,67 & 3,43 & 2,99 & 1,99 & 1,67 & 1,53 \\
\hline \multicolumn{12}{|c|}{ Yapıșma dayanımı standart sapma: 0,66} & \multicolumn{11}{|c|}{ Yapıșma dayanımı standart sapma: 0,78} \\
\hline \begin{tabular}{|l|} 
Yapışma \\
dayanımı \\
değişim \\
$(\%)$
\end{tabular} & 0 & 1 & 4 & 10 & 18 & 16 & 12 & -19 & -28 & -37 & -52 & 0 & 5 & 13 & 26 & 33 & 31 & 22 & 7 & -28 & -40 & -45 \\
\hline \multicolumn{23}{|c|}{ Selsil (\#60) } \\
\hline & \multicolumn{11}{|c|}{ Partikül boyutu: $7 \mathrm{~nm}$} & \multicolumn{11}{|c|}{ Partikül boyutu: $20 \mathrm{~nm}$} \\
\hline \begin{tabular}{|l|}
$\begin{array}{l}\text { Partikül } \\
\text { oranı } \\
(\%)\end{array}$ \\
\end{tabular} & 0 & 0,5 & 1 & 1,5 & 2 & 2.5 & 3 & 3,5 & 4 & 4,5 & 5 & 0 & 0,5 & 1 & 1,5 & 2 & 2,5 & 3 & 3,5 & 4 & 4,5 & 5 \\
\hline $\begin{array}{l}\text { Yapışma } \\
\text { dayanımı } \\
\text { (Mpa) }\end{array}$ & 3,07 & 3,19 & 4,25 & 4,84 & 5,30 & 5,45 & 5,27 & 5,01 & 4,5 & 4,23 & 3,61 & 3,07 & 3,26 & 4,51 & 5,73 & 6,49 & 6,61 & 5,45 & 4,87 & 4,53 & 3,41 & 3,12 \\
\hline \multicolumn{12}{|c|}{ Yapışma dayanımı standart sapma: 0,84} & \multicolumn{11}{|c|}{ Yapıșma dayanımı standart sapma: 1} \\
\hline $\begin{array}{l}\text { Yapışma } \\
\text { dayanımı } \\
\text { değişim } \\
(\%)\end{array}$ & 0 & 3 & 38 & 57 & 72 & 77 & 71 & 63 & 46 & 37 & 17 & 0 & 6 & 46 & 86 & 111 & 115 & 77 & 58 & 47 & 11 & 1 \\
\hline
\end{tabular}

\section{SONUÇLAR}

Çalışmada yüzey pürüzlülüğünün, nanopartikül karışım oranının ve nanopartikül çapının yapışma dayanımına etkileri incelenmiştir. Yapıştırıcı çeşidi, nanopartikül türü ve çapı, uygulanan yüzeyin pürüzlülük durumları gibi birçok değişkenin olduğu deney şartlarında yapılan bu çalışmadan elde edilen sonuçlara göre nanopartiküllerin yapışma dayanımına olumlu ve olumsuz etkileri tespit edilmiştir. Her iki yapıştırıcıda da yüzey pürüzlülüğü, nanopartikül çapı ve nanopartikül oranının belli bir orana kadar artmasıyla yapışma dayanımı artış göstermiştir. 
Genel olarak değerlendirildiğinde yapışma dayanımlarında $\% 2$ veya $\% 2,5$ nanopartikül oranlarında maksimum seviyeye ulaşılırken bu oranların üzerine çıkıldığında düşüşler başlamıştır. $\mathrm{Bu}$ durum giriş kısmında verilen literatür çalışmalarını da desteklemektedir. \%3,5 veya $\% 4$ oranlarından sonra nanopartiküllerin olumlu etkisi kaybolurken $\% 5$ oranında ( 1 durum hariç) olumsuz etkiler görülmüş ve yapışma dayanımında katkısız halden daha düşük değerler elde edilmiştir. Bunun sebebinin partikül oranı fazlalığ 1 sebebiyle yapıştırıcı moleküllerinin hem yapışan yüzeylerde hem de kendi içerisinde uygun bağlar oluşturamaması olduğu düşünülmektedir. Yapışma dayanımındaki en yüksek değişim \%115 oranında Selsil yapıştırıcısı, kalın zımparalı yüzey, \%2,5 partikül oranı ve $20 \mathrm{~nm}$ partikül çapında elde edilmiştir.

\section{TEŞEKKÜR}

$\mathrm{Bu}$ çalışma, Sivas Cumhuriyet Üniversitesi Bilimsel Araştırma Projeleri (CÜBAP) tarafından TEKNO-008 proje numarası ile desteklenmiştir. Katkılarından dolayı Sivas Cumhuriyet Üniversitesi Bilimsel Araştırma Projeleri Koordinatörlüğüne teşekkür ederim.

\section{KAYNAKLAR}

1. Aydın, S., 2012. Yapıştırıcı ile Birleştirilmiş Prizmatik Geçmeli Bağlantıların Mekanik Analizleri, Doktora Tezi, Fen Bilimleri Enstitüsü, Fırat Üniversitesi, Elazığ.

2. Hsiao, K.T., Alms, J., Advani, S.G., 2003. Use of Epoxy/multiwalled Carbon Nanotubes as Adhesives to Join Graphite Fibre Reinforced Polymer Composites. Nanotechnology 14, 791-793.

3. Panta, J., Jagannatham, M., Prathap, H., Ram, G.D.J., Deshpande, A.P., Bakshi, S.R., 2016. Effect of Different Carbon Nano-fillers on Rheological Properties and Lap Shear Strength of Epoxy Adhesive Joints Composites A, 82, 53-64.

4. Florian, G., Malte, W., Bodo, F., Schulte, K., 2005. Influence of Different Carbon Nanotubes on the Mechanical Properties of Epoxy Matrix
Composites-A Comparative Study. Composites Science and Technology. 65, 2300-2313. 10.1016/j.compscitech.2005.04.021.

5. Saeed, M.B., Zhan, M.S., 2007. Adhesive Strength of Nano-size Particles Filled Thermoplastic Polyimides. Part-I: Multi-walled Carbon Nano-tubes (MWNT)-polyimide Composite Films, Int. J. Adhes. Adhes., 27, 306-318.

6. Lanlan, Z., Guoping, L., Jian, L., Youwen, W., 2006. The Effect of Nanoparticles on the Adhesion of Epoxy Adhesive, Materials Letters, 60, 3031-3033.

7. Gültekin K., Akpinar S., Gürses A., Eroglu Z., Cam S., Akbulut, H., Keskin, Z., Özel, A., 2016. The Effects of Graphene Nanostructure Reinforcement on the Adhesive Method and the Graphene Reinforcement Ratio on the Failure Load in Adhesively Bonded Joints, Composites Part B, 98, 362-369.

8. Akpinar, İ.A., Gültekin K., Akpinar, S., Akbulut, H., Özel, A., 2017. Research on Strength of Nanocomposite Adhesively Bonded Composite Joints, Composites Part B, 126, 143-152.

9. May, M., Wang, H.M., Akid, R., 2010. Effects of the Addition of Inorganic Nanoparticles on the Adhesive Strength of a Hybridsol-gel Epoxy System, International Journal of Adhesion \& Adhesives, 30, 505-512.

10. Wernik, J.M., Meguid, S.A., 2014. On the Mechanical Characterization of Carbon Nanotube Reinforced Epoxy Adhesives. Materials \& Design, 59(0), 19-32.

11. Razavi, S.M.J., Ayatollahi, M.R., Nemati, G.A., Khoramishad, H., 2018. Single Lap Joints Bonded with Structural Adhesives Reinforced with a Mixture of Silica Nanoparticles and Multi Walled Carbon Nanotubes, International Journal of Adhesion and Adhesives, 80, 76-86.

12. Douba, A., Genedy, M., Matteo, E.N., Kandil, U.F., Stormont, J., Reda, T.M.M., 2017. The Significance of Nanoparticles on Bond Strength of Polymer Concrete to Steel, International Journal of Adhesion \& Adhesives, 74, 77-85.

13. Andrew, J., McNamara, Y.J., Zhuomin, M.Z., 2015. Thermal Resistance of Thermal 
Conductive Adhesive Anchored Carbon Nanotubes Interface Material, Int. J. Thermal Sci., 96, 221-226.

14. Suzhu, Y., Tong M.N., Critchlow, G., 2010. Use Ofcarbon Nanotubes Reinforced Epoxy as Adhesives to Join Aluminum Plates. Materials and Design, 31, 126-129.

15. Chena H., Jacobs O., Wua W., Rudiger G. Schadel B., 2007. Effect of Dispersion Method on Tribological Properties of Carbon Nanotube Reinforced Epoxy Resin Composites. Polymer Testing 26, 351-360.

16. Aydın, S., Fertelli, A., 2018. Nanopartikül ve Yüzey Pürüzlülüğünün Yapışma Mukavemetine Etkilerinin İncelenmesi, Academic Perspective Procedia, 1(1), 1164-1170. 